\title{
Exergy as Measure of Sustainability of Energy System
}

Peter Novak

Faculty for Technologies and Systems, Novo mesto, Slovenia

\begin{abstract}
Exergy is a measure of energy quality. The amount of exergy in energy carriers is very different. Normally the price includes only the value of quantity and not the quality of energy. Exergy is the only part of energy available to do work. For different purposes we need energy with different amounts of exergy: for heating and cooling the energy mixture between small amount of the exergy and large part anergy is needed. Transition to sustainable energy system, without GHG emissions, based on RE, open the questions how to evaluate exergy from solar energy. Solar energy in all form (irradiation, water flows, wind, and biomass) consists of nearly $100 \%$ of exergy. Solar energy is free, conversion systems are not. To exploit at maximum the solar exergy we need a sustainable energy system using in great amount the present infrastructure and existing or new developed energy conversion technologies. There is common agreement that we need four main presently used energy carriers: electricity, gaseous, liquid and solid fuels.
\end{abstract}

Our vision is the new Sustainable Energy System (SES) based on the use of solar and planetary energy for production of renewable electricity as a base for production of hydrogen. Hydrogen is a raw material for carbon recycling from biomass, making synthetic methane and methanol. The proposed SES is based on the existing infrastructure and known chemical processes. With regard to availability of renewable energy resources (RES) it is unrestricted and harmless in comparison to present fossil fuels use. The proposed SES consists of the three main exergy carriers: solar electricity, synthetic methane $(\mathrm{CH} 4)$ and synthetic methanol $(\mathrm{CH} 3 \mathrm{OH})$.

\section{Introduction}

In the last years European Union (EU) in conformity with Paris Agreement has adopted many regulations and decisions with regard to energy management [1] including the EU Council decision on $40 \%$ greenhouse gas emission (GHG) reduction and the share of $27 \%$ of renewable energy (RE) in final energy (FE) until 2030. The common goal of these regulations is to change the present energy system to a sustainable one. In EU winter package documents is one of the most important statements: "To reach our goal, we have to move away from an economy driven by fossil fuels, an economy where energy is based on a centralized, supply-side approach and which relies on old technologies and outdated business models [2]."

There are different ways and timing to achieve the proposed goals. One possibility is to integrate all those activities into Circular Economy [3]. What should be a "sustainable development" in the case of energy supply, distribution and use? How can we measure the sustainability of energy system?

Can we have a sustainable energy system with the circulation of organic carbon, going away from the expression "a low carbon society" to a carbon recycling economy?

We presented one of the possible solutions including tools for evaluation of their sustainability. Based on previous research results and proposals [4-8] we find, that one of the best criteria for measuring the sustainability of energy system is exergy approach.

Normally we are selling fuels, electricity, heat and cold. The amount of exergy in these energy carriers is very different. In their prices only the quantity and not the quality of energy is included. This means the value or amount of exergy, as the measure of quality, in it is not always included in the price. But in real life we need energy with a different

\section{Publication History:}

Received: August 14, 2017

Accepted: October 24, 2017

Published: October 26, 2017

\section{Keywords:}

Energy, Exergy, Evaluation, Sustainable exergy system amount of exergy: for heating and cooling energy mixture between small amount of the exergy and large part anergy is needed. For work and lighting the $100 \%$ of exergy is needed.

The transition to sustainable energy system, without GHG emissions, based on RE, opens the questions how to evaluate exergy from solar energy. How important are the irreversibility's of our processes in solar energy conversion system? The answer is only possible if we know what type of processes will be used. There is common agreement that we need in practice a sustainable energy system with four main energy carriers: electricity, gaseous, liquid and solid fuels to exploit at maximum the present infrastructure.

\section{Exergy}

The word "exergy" was introduced by Zoran Rant [9] and the present common definition is: "exergy of a system in a certain environment is the amount of mechanical work that can be maximally extracted from the system in this environment".

According Rant the energy $\mathrm{W}$ is a sum of exergy $\mathrm{Ex}^{1}$ and anergy $\mathrm{A}$ ( energy of environment)

$$
\mathrm{W}=\mathrm{Ex}+\mathrm{A}
$$

'Symbol Ex is used for exergy, to distingwish betwen symbol E many authors used for energy or exergy.

"Corresponding Author: Prof. Peter Novak, Faculty for Technologies and Systems, Novo mesto, Slovenia; E-mail: peter.novak@energotech.si

Citation: Novak P (2017) Exergy as Measure of Sustainability of Energy System. Int J Earth Environ Sci 2: 139. doi: https://doi.org/10.15344/2456-351X/2017/139

Copyright: ( 2017 Novak. This is an open-access article distributed under the terms of the Creative Commons Attribution License, which permits unrestricted use, distribution, and reproduction in any medium, provided the original author and source are credited. 
Exergy is a measure of quality of energy. Energy is always conserved and can neither be produced nor consumed. Exergy can be very easily converted in anergy through irreversibilities in the conversion processes. Therefore the most used expression in daily life "consumption of energy" should be changed to "consumption of exergy" as the only thermodynamically correct expression.

Our attention will be given to the exergy of renewable sources of energy as the core of future energy system. With regard to energy carriers, exergy in the system can be also quantified into several different types of exergy, such as: $\mathrm{Ex}_{\mathrm{ch}}-$ chemical, $\mathrm{Ex}_{\mathrm{nu}}-$ nuclear, $\mathrm{Ex}_{\mathrm{ph}}$ - physical, $\mathrm{Ex}_{\mathrm{k}}=\mathrm{v}^{2} / 2$ - kinetic ( $\mathrm{v}$ - velocity), $\mathrm{Ex}_{\mathrm{p}}=\mathrm{gZ}$ - potential ( $\mathrm{g}-$ gravitational constant, Z-height above the lowest level in environment) and $\mathrm{E}_{\mathrm{xr}}$ radiation exergy.

$$
\mathrm{Ex}=\mathrm{Ex}_{\mathrm{ch}}+\mathrm{Ex}_{\mathrm{nu}}+\mathrm{Ex}_{\mathrm{ph}}+\mathrm{v}^{2} / 2+\mathrm{gZ}+\mathrm{Ex}_{\mathrm{r}}
$$

In real energy conversion processes we always have a loss of exergy. This means that energy can be balanced but the exergy in a closed system cannot be. Exergy destruction or vanishing of exergy because of irreversibilities is a natural phenomenon which can be to some extent controlled by design of our energy conversion equipment. Exergy efficiency is therefore a quality measure of our processes. The quotient between output exergy Exout and input exergy $\mathrm{Ex}_{\mathrm{in}}$ is the standard definition of exergy efficiency.

$$
\varepsilon=\mathrm{Ex}_{\text {out }} / \mathrm{Ex}_{\text {in }}
$$

Using standard data for exergy content in different energy carriers and the embedded exergy in materials used in practice [10] we can calculate this efficiency. Besides the exergy efficiency it is important also to analyze the exergy destruction in processes during the time.

\section{Exergy, sustainability and resource accounting}

Resources cannot be evaluated only according to mass and energy balance, because they do not disappear. Using the exergy as the measure of resource depletion we can evaluate the quality of our processes taking into account the conservation of mass and energy.

Exergy is closely connected with sustainability. Sustainable development means less exergy destruction or depletion. Circular economy promoted in the last years is a policy to minimize the resource destruction, to minimize the thermodynamics irreversibilies with higher exergy efficiency. To push the circular economy on the top of society development we need a serious exergy analysis (ExA) of present technologies and economic patterns. The millennium goal "living well within the limits of the planet", set out in UN and $\mathrm{EU}$ can be reduced to conclusions that any citizen has a minimum of sustainable commodities such as: exergy or/and adequate mixture anergy-exergy, food (secondary type of exergy), drinking water, home and jobs with a salary able to cover the cost of those commodities.

The exergy destruction during a process is proportional to the entropy created due to irreversibilities associated with the process. Exergy analysis can clearly indicate the locations of energy degradation in a process that may lead to improved operation or technology. It can also quantify the heat quality in rejected streams. The main aim of exergy analysis is to identify the causes of irreversibilities and to calculate the true magnitudes of exergy losses.

Exergy analysis [8] is a methodology that uses the conservation of energy principle (embodied in the first law of thermodynamics) together with non-conservation of entropy principle (embodied in the second law) for the analysis, design and improvement of energy and other systems.

The exergy method is useful for improving the efficiency of fossil and renewable energy-resource use, for quantification of the destruction locations, types and magnitudes of wastes and losses.

LCExA (Life Cycle Exergy Analysis) can be used as a method to quantify depletion of natural resources and to assess the efficiency of natural resource used. It can be used for energy system with fossil and renewable sources of energy, for different materials and in broader sense for exergy of societies. In our case LCExA will be used to analyze sustainability of proposed exergy system, based on organic carbon circulation in future circular economy.

\section{Life Cycle Exergy Analysis of Renewable Energy}

The use of exergy in life cycle assessments (LCExA or sometimes ExLCA) has been suggested by many different researchers since the late 1990s. Based on work of Davidsson using LCExA for wind energy system analysis [7], where the renewable resources are separated from non-renewable, we accept the same methodology.

Natural resources are classified as natural flows and stocks. Stocks are then divided into funds (living stocks) and deposits (dead stocks). Natural flows and funds are renewable while deposits are nonrenewable. All in- and outflows during the life cycle of production, use and disposal or recycling, are then considered as exergy power over time.

The direct solar exergy input (e.g. solar irradiation, water, wind, waves) of renewable sources (including geothermal and planetary exergy) can be disregarded since they represent a natural flow and are therefore renewable. If not used natural exergy flows will be wasted and lost as anergy - heat of environment. Non-sustainable use of exergy funds, like clearing of forests in a non-sustainable fashion and the use of exergy deposits are regarded as non-renewable resources. The simple presentation of LCExA is given in $[7,32]$ and is shown on the Figures 1, 2 and 3.

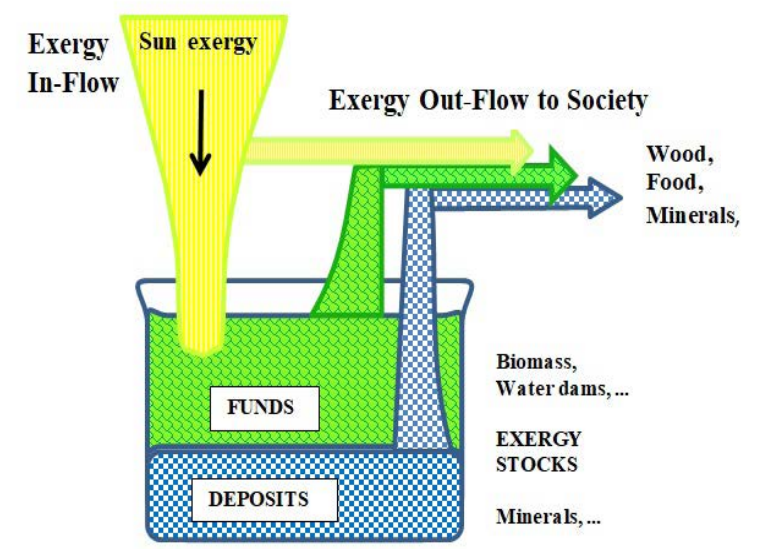

Figure 1: The exergy flow from the sun and the exergy stocks on the earth create the resource base for human societies on the earth $[7,32]$. 
The life cycle analysis of a system usually consists of three separate stages with different exergy flows that are analogous to the three steps in the life cycle of a product in:

1- Construction phase,

2 - Operational phase and

3 - Clean up phase.

During the construction phase, exergy is spent and none is created besides eventual byproducts. Some exergy is used for maintenace and at end of life we need the exergy for clean up (recycling) of the equipment or plant. The exergy used for construction combined with the exergy used for maintenance and clean up make up the total indirect exergy. It is also very important at what moment in time the exergy is needed (storage problem of RE). The LCExA of the two different power plant explain the differences.
A fossil fuels power plant takes the exergy from the fuels used for construction, during the operational phase and clean up. The exergy of output electricity will always be lower than the exergy of the fuels used. A power plant using fossil fuels can therefore never be sustainable since it uses more exergy than it generates. The exergy flow over the lifetime of a fossil fuel power plant is illustrated in Figure $2[7,32]$.

The power plant using the renewable sources of energy for electricity production, on the other hand, converts the natural exergy flows to a useable form of exergy - electricity. As an example, a PV panel uses the solar exergy to convert it into electricity and same is done by the wind generators.

During the operational phase it will hopefully produce more exergy than the indirect exergy needed during the life cycle (for construction, maintenance and clean up). The exergy flow over the life cycle of such one power plant is illustrated in Figure 3 [7,32]. The fact that the exergy

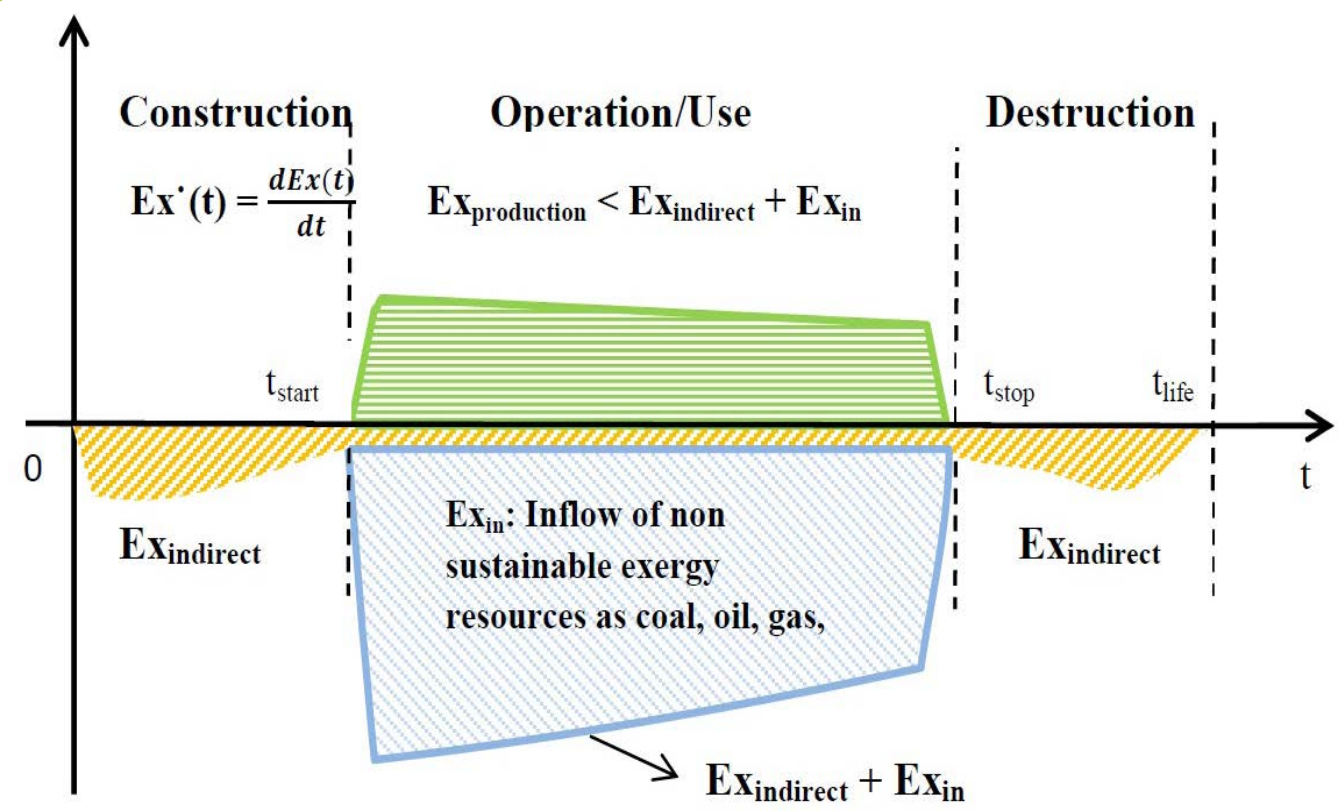

Figure 2: Exergy flow diagram for LCExA of a power plant using fossil fuels [7, 32].

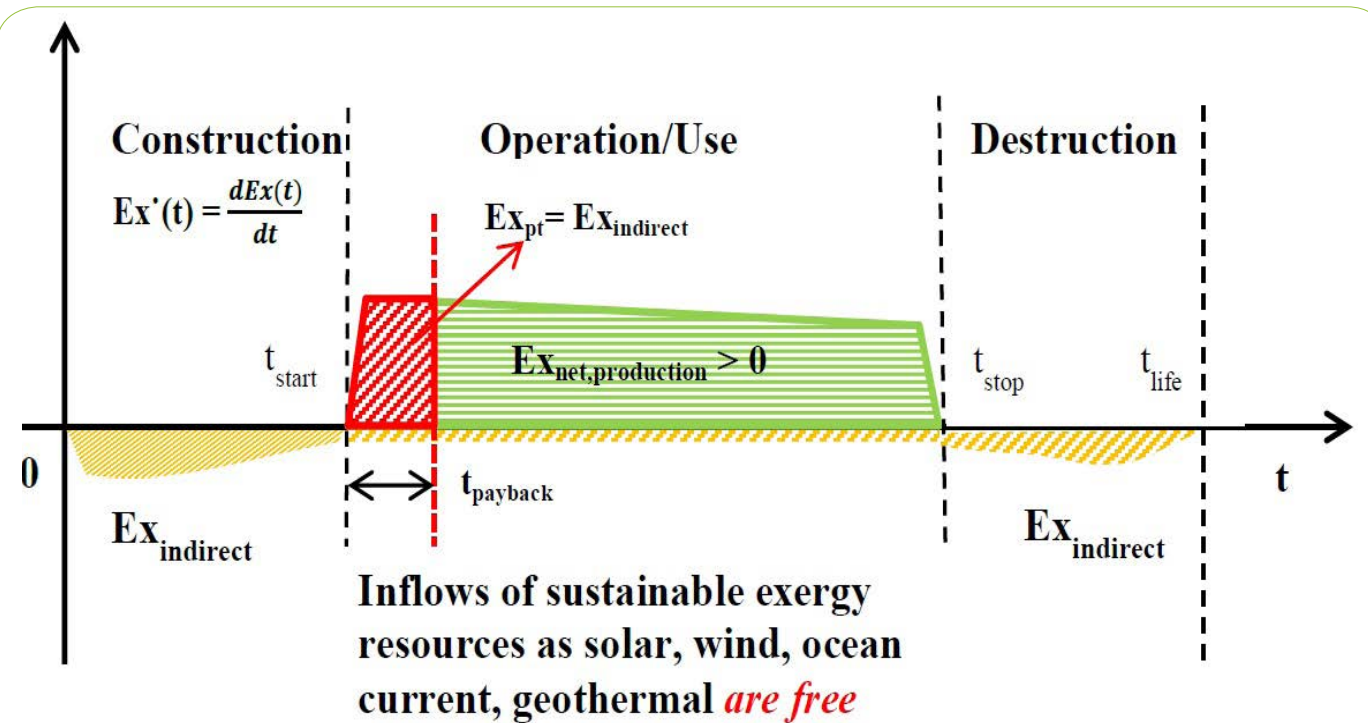

Figure 3: Exergy flow diagram for LCExA of a renewable energy power plant $[7,32]$. 
utilized during the operational phase of the life cycle comes from a renewable source does however not automatically mean that it is always sustainable. Some solar heat conversion technologies using high exergy demanded materials can actually use more indirect exergy than it will ever generate during its life cycle (some solar collector design). With LCExA method it is possible to investigate this kind of issues.

LCExA method enables us also to analyze the influence of intermittency of RE taking into account the power factor $\mathrm{CP}$ and the capacity factor $\mathrm{CF}$ by producing heat and electricity. In this context we have to include storage systems which influence the exergy needed in the construction phase.

Sustainable engineering could be defined as systems which make use of renewable resources in such a way that the input of exergy will be paid back during its life time, or before, i.e.,

$\mathrm{Ex}_{\mathrm{pr}}>\mathrm{Ex}_{\mathrm{in}}+\mathrm{Ex}_{\text {indirect }}$, and the used deposits are completely restored or even better not used at all. Thus, by using LCExA and distinguishing between renewable and non-renewable resources we have a method to define sustainable engineering [32].

The exergy (energy) conversion and use is usually presented either as exergy payback time (ExPBT) or exergy return of invested exergy (ExROExI) as indicators for sustainability [28]. The way the energy is compared can be a bit different between different assessments. In case of exergy produced from RE the ExPBT should be defined as:

$$
\text { ExPBT }=\frac{\text { Cumulative exergy required }}{\text { Cumulative exergy generated }} \text { [years] }
$$

and for

$$
\text { ExROExI }=\frac{\text { Cumulative exergy required }}{\text { Cumulative exergy generated }}=\frac{\text { lifetime }}{\text { ExPBT }}[-]
$$

Cumulative exergy generated includes exergy generated during the operation time. Cumulative exergy required includes exergy of construction materials, maintenance, exergy needed for operation and destruction, minus exergy available because of recycling of some materials.

The use of ExPBT and EROExI defined in [4,5] are fairly good indicators that an exergy producing process actually produces more exergy than it uses during its life cycle, without regard to the source of exergy required.

If the ExPBT should be used also for the presumptions of the costs of exergy (in present practice as cost of energy), the MJ or kWh of exergy must be multiplied with agreed costs in time of analysis or agreed costs changes during the life cycle time.

The value of ExPBT for fossil fuels is always less than 1 (unsustainable). The value of ExPBT over 1 means sustainable conversion of exergy. Break-even point between sustainable and un-sustainable energy device is also for ExROExI value of 1 (Figure 4).

Exergy per se is NOT a measure of environmental impact, but in essence at the end of the life cycle of any device, plant and product, the exergy "balance" of the extraction- transformation -productiondistribution-use-disposal cycle shows how many primary exergy resources have been actually used up (consumed) [7,32]. Using the renewable energy in our proceses we expect a minimum of environmental impacts, even they can not be totaly eliminated.

\section{The Exergy of Renewable Energy}

Renewable energy forms considered in our study are: solar irradiation on the Earth surface, wind, water flows, waves, and planetary (geothermal, tidal) energy. Biomass is accumulated solar energy and is taken as funds - reserves. In literature different data are

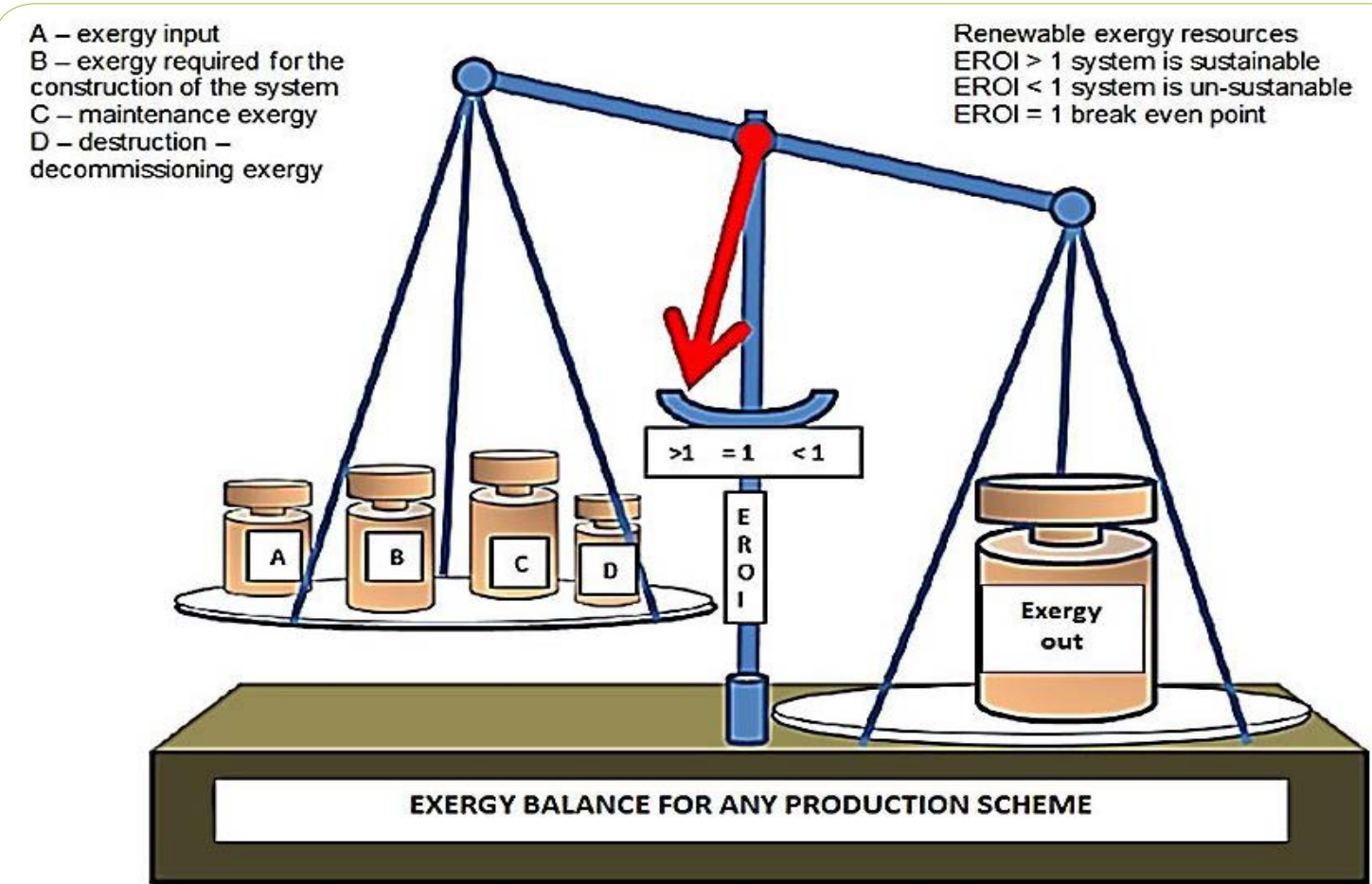

Figure 4: Exergy balance for any production scheme [7]. 
Page 5 of 11

given about global resources of RE on the Earth surface. We accept the data from $[11,12$, and 13] presented on Table 1 . From the data we can conclude that available resources prevail all present primary energy or exergy needs of humans for many hundred times (if we take into account only the technologies developed up to day).

\begin{tabular}{|l|l|l|l|}
\hline $\begin{array}{l}\text { Resource in TW } \\
\text { TWh/8760 h/y }\end{array}$ & $\begin{array}{l}\mathrm{TW}_{\text {ex }} \\
\text { Ideal }\end{array}$ & $\begin{array}{l}\mathrm{TW}_{\mathrm{ex}} \\
\text { Technical } \\
\text { possible }\end{array}$ & $\begin{array}{l}\mathrm{TW}_{\mathrm{ex}} \\
\text { Present delivery } \\
\text { as electricity }\end{array}$ \\
\hline Solar irradiation & 11500 & $580 \div 1640$ & 0.00176 \\
\hline Wind & 1700 & $40 \div 170$ & 0.02 \\
\hline Water flows & 1.9 & $1.6 \div 1.9$ & 0.32 \\
\hline Waves & 2,7 & $0.5 \div 2.7$ & 0.000002 \\
\hline $\begin{array}{l}\text { Geothermal- } \\
\text { shallow }\end{array}$ & 45 & $0.07 \div 0.2$ & 0.0065 \\
\hline Geothermal - deep & 55 & $0.035 \div 2$ & 0.0065 \\
\hline Tidal & 3.7 & $0.02 \div 0.8$ & 0.00006 \\
\hline Biomass (dry) & 33.4 & $5.8 \div 11.7$ & 0.039 \\
\hline Total & $13,341-7$ & $628.03 \div 1829.3$ & 0.387322 \\
\hline $\begin{array}{l}\text { Present world } \\
\text { TPES* (2013) }\end{array}$ & 17.79 & 2.5877 & \\
\hline $\begin{array}{l}\text { Table 1: Renewable exergy (energy) resources on the Planet Earth with } \\
\text { present conversion technologies in electricity [11, 12 and 13] } \\
\text { * TPES - Total Primary Energy (exergy) Supply }\end{array}$ \\
\hline
\end{tabular}

Solar exergy availability

Zamfirescu and Dincer [5] show that ideal conversion effectiveness of total normal solar radiation is time and scattering in the atmosphere dependent. The obtained values of $\eta \mathrm{ex}, \mathrm{S}$ are between 0.82 to 0.95 . From real solar irradiation data for Italy Neri found out [6] the average exergy efficiency of $\eta_{\text {ex, IT }}=0.839$. Some other authors [4] found out that we have to include the entropy production at solar exergy conversion at the device, if the temperature mismatches between the incoming radiation temperature and the temperature of the surface of the device (similar to entropy production in heat transfer).

The entropy production can approach zero if the receiver surface approaches the average thermodynamic temperature of the incoming radiation. For South European region(latitude 37 to $47^{\circ}$ ) we can use the relation for exergy loss from incoming solar energy to the surface level nex developed from [6]:

$$
\eta_{\text {ex }, \mathrm{S}}=0.820+1.76 .10^{-5} \cdot\left(\mathrm{G}_{\mathrm{tot}}-4500\right)
$$

Where: $G_{\text {tot }}=G_{D}+G_{d}\left[M J / \mathrm{m}^{2} /\right.$ year $]$ is the sum of yearly direct (D) and diffuse $(\mathrm{d})$ radiation that reaches a horizontal surface on analyzed location. Equation (6) is valid for $\mathrm{G}_{\text {tot }}=4500$ to $7000 \mathrm{MJ} / \mathrm{m}^{2} /$ year.

\section{Exergy of other forms of solar energy}

Wind and water flow are the secondary and waves are the tertiary exergy form of solar irradiation. Waves are the result of wind exergy transfer on the water surface because of shear forces between air flow and water [11]. The available exergy is time and location depended and calculation can be done only on the basis of measured data in given period of time, normally more than 2 typical meteorological years. Yearly data of wind velocity distribution and for yearly water flow distribution at given height differences are input to calculate the available theoretical exergy potential on the given location.

\section{Sustainabale Exergy (Energy) System Based On RE}

\section{Concept}

Solar exergy is characterized by low density, high intermittency over day and year. The concentration of available solar exergy and storage system are needed for practical application. Different sustainable energy systems have been proposed using water, wind and direct solar irradiation including geothermal heat and biomass. Most of them have no integral solution for exergy storage and transition technologies from present to a new, environmentally acceptable, energy system [11].

The sustainable exergy system (SES) as proposed in [16] consists of three main renewable exergy (energy) carriers, needed in industry, transport, services and homes renewable electricity, gas (synthetic methane $\mathrm{CH}_{4}$; s-methane), liquid (synthetic methanol $\mathrm{CH}_{3} \mathrm{OH}$; s-methanol) and as fourth solid fuels from biomass (important for developing countries). Renewable electricity is the main driver in the system used for transformation of two natural flows, water and biomass into two new exergy carriers used also as chemical storage of solar electricity (Figure 5). The methane and methanol are chosen, because there are only exergy carriers in nature with one carbon chemically connected with four hydrogens. The necessary hydrogen and oxygen will be produced with electrolysis of water or other processes, equalizing the sun daily and yearly irradiation variations. Carbon will be taken from biomass where is stored trough photosynthesis from the air. For solid fuels (in transition period) we propose to use only the wood log.

S-methane and s-methanol represent the chemical storage of solar exergy (like do the nature in biomass) with exergy efficiency close to the storage of atmospheric carbon in biomass. In this way, the natural circle of carbon dioxide and water is closed. The proposed SES has no GHG emissions, because $\mathrm{CO}_{2}$ and water are recycled in natural photosynthesis and vapor cycle process.

We muss stress out that these exergy carriers can be produced and used in well-developed energy conversion equipments and infrastructure in industry, buildings and transportation. To these three exergy carriers we can add in transition period also bio fuels as ethanol $\left(\mathrm{C}_{2} \mathrm{H}_{5} \mathrm{OH}\right)$, dimethyl-ether $\left(\mathrm{CH}_{3} \mathrm{OCH}_{3}\right)$, and synthetic diesel made from the rests of biomass and organic waste. The last survey show, that methanol can be used on different ways in different internal combustion (IC) spark ignition (SI) engines with low emissions and high break thermal efficiency [35]. Methanol is a transportation fuel and has many significant advantages as compared to hydrogen, gasoline and can be in new turbocharged methanol engines good replacement for heavy duty diesel engines. Higher efficiency (nearly $43 \%$ ) ower the wide range of motor speeds and loads in comparison to the standard diesel engines made methanol interesting fuel of the future.

\section{Characteristics of sustainable (renewable) exergy system - SES}

To fulfil the daily exergy needs of different consumers, the new exergy system has to response to the following six main requirements:

1. Source of exergy must be inexhaustible, available everywhere on the planet;

2. Using exergy carriers with zero emission of GHG; 


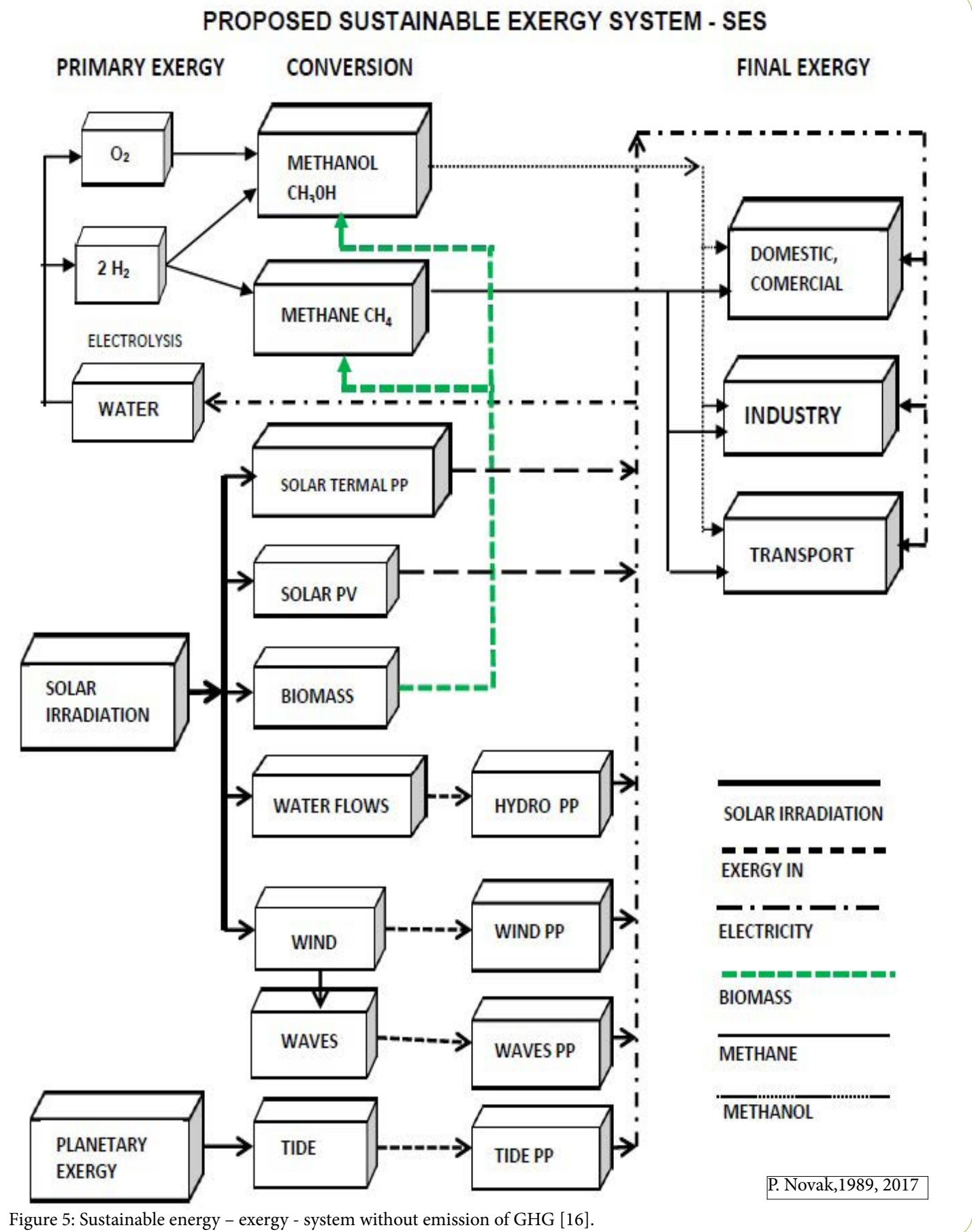

3. Available at any place and any time (in all present forms of exergy needed: solid, liquid, gaseous fuels and electricity);

How does the proposed SES comply with the six requirements?

Primary exergy sources

4. Must be compatible with existing infrastructure, with minor adaptations;

5. In transition period the present energy system and SES have to work in parallel with no interference (coexistence of two systems);

6. Should be competitive with fossil fuels system if all external none acknowledged environmental costs will be included in their price.

The first primary exergy source in the system is the solar energy (including direct irradiation and all secondary forms of solar exergy: biomass, water, wind, waves), the second is the planetary energy (geothermal heat and tide). These exergy sources are inexhaustible, generally available for the lifetime of mankind (see the data in T-1). Solar irradiation on the planet is about $174.10^{3} \mathrm{TWy} / \mathrm{y}$. In $2013 \mathrm{TPES}$ (Total Primary Exergy Supply) on the planet was only $17.98 \mathrm{TWy} / \mathrm{y}$. Converting only $\sim 0.01033 \%$ of solar irradiation we can cover all present exergy needs for the world population. 


\section{No emission of GHG}

The burning products of synthesized s-methane and s-methanol are water and $\mathrm{CO}_{2}$. Water normally circulates in the atmosphere. Carbondioxide is released back into the atmosphere and is used for plants growth ( 200 Gt/y, [12]).

According to our proposal intermittent solar radiation is chemically stored in two chemicals (s-methane and s-methanol) which can be used as standard gaseous and liquid fuels. At the same time they can be used for production of electricity during winter and night time. In transition period part of biomass in the form of logs, exceptionally as pellets, can be used as solid fuels.

According to our proposal intermittent solar radiation is chemically stored in two chemicals (s-methane and s-methanol) which can be used as standard gaseous and liquid fuels. At the same time they can be used for production of electricity during winter and night time. In transition period part of biomass in the form of logs, exceptionally as pellets, can be used as solid fuels.

\section{These four energy carriers can be used at any time at any place}

Renewable electricity, s-methane, s-methanol and wood can be used anytime and anywhere.

\section{For the proposed system we do not need a new infrastructure}

Solar electricity can be transported through existing grid on low and high voltage AC and DC lines. New HVDC lines can be constructed and smart grid will be locally introduced. For storage of surplus of electricity, the hydrogen production will take place on location where water and biomass will be available. Biomass conversion efficiency is much depended from collection and transportation costs.

Hydrogen can be also locally used in gas turbines, fuel cells etc. for demand side management of electricity supply. Oxygen for burning and/or syntheses processes will be available in the same place as hydrogen production. Synthetic gas can be supplied via existing gas pipelines for natural gas (hybrid system in transition period). In this way a high efficient combined cycle gas-steam power plant can be realized with the efficiency of over $60 \%$ (not including the exergy efficiency of solar power plant).

Liquified s-methane can be used as LNG for transportation in the transition period.

The distribution of liquid methanol is well developed and normal gas stations can be (with minor adaptation) used for cars and trucks with adopted or new methanol engines [35]. New engines for hybrid cars can be very efficient because of higher pressure ratio of methanol. Using the two stroke engine with turbocharger, its power/weight ratio can be doubled.

Heating systems based on s-gas do not need any adaptations or new infrastructure. The boiler using heating oil can be used further, modifying only the burner to use the s-methanol.

\section{Coexistence with present energy system}

All four energy carriers can coexist with the present energy system. The transition from the present system to a sustainable one is simple and can be implemented very smoothly. In towns and buildings it does not require a new local infrastructure. Bio-ethanol can also be used in the transition period in the system if the production and distribution will be competitive to s-methanol.

\section{Should be competitive}

The answer to this requirement is difficult. All technologies for the conversion are almost well developed (solar cells, wind generator, hydro PP, electrolysis, methanol syntheses, etc.). Methane and methanol synthesis are old, known processes. New processes for direct conversion of $\mathrm{CO}_{2}$ and hydrogen to methanol are under development. The costs of renewable energy conversion are falling and in some cases LCOE (Levelized Costs of Exergy) is competitive with fossil fuels according to data in Table 2 [14]). Solar electricity is presentlly more expensive, except large hydro and in some cases wind and PV, than electricity from old fossil or nuclear power plant. The situation can change if environmental impacts of burning fossil fuels are included in their price.

\begin{tabular}{|l|l|}
\hline Power Plant Type & Cost $\$ / \mathrm{kWh}$ \\
\hline Coal & $\$ 0.11-0.12$ \\
\hline Natural Gas & $\$ 0.053-0.11$ \\
\hline Nuclear & $\$ 0.096$ \\
\hline Wind & $\$ 0.044-0.20$ \\
\hline Solar PV & $\$ 0.058$ \\
\hline Solar Thermal & $\$ 0.184$ \\
\hline Geothermal & $\$ 0.05$ \\
\hline Biomass & $\$ 0.098$ \\
\hline Hydro & $\$ 0.064$ \\
\hline
\end{tabular}

Table 2: The latest costs comparisons of kWh electricity from fossil fuels and RE [14].

It is well known that world pretax subsidies for fossil fuels are distorting the energy/exergy market and expand considerably. In year 2011 fossil fuels subsidies go up to $\$ 523$ billion/y (up 30\%), compared to all subsidies for renewable energy which amounted only $\$ 88$ billion/y. According to IMF report (January 2013), the world fossil fuel pre-tax subsidies in 2013 have been $\$ 480$ billion/y and post-tax subsidies $\$ 1.9$ trillion/y. Including the $\$ 1.4$ trillion/y environmental damages, total direct and indirect costs, not included in the price of fossil fuels used are $\$ 2.78$ trillion/y. Including these subsidies in the final price of fossil fuels, competitiveness of RE will be out of question.

Great importance for the sustainability of the system is build-up adequate exergy storage. Some storage systems must be developed for electricity (batteries), if storage in s-methane and s-methanol does not satisfy the consumption pattern.

The investment in RE conversion technologies must be based on LCEA, but taking into account the fossil fuels subsidies which will slowly disappear.The new investment in SES should be the primary goal and equivalent to abatement costs of GHG emissions. Exergy independency and security of supply is the second most important reason for such decision.The proposed SES is not totally new, but enables a smooth transition to a new sustainable carbon recycling society, which is not on political agenda as low carbon society". SES is sustainable part of promoted circular economy. Costs of all forms of exergy will be at the beginning of transition period higher, but at the 
end of transformation of present energy system to SES will be lower and stable for ever with a minor or no impact on the planet climate [11].

\section{Exergy as Measure of Sustainabilaty of Ses}

Exergy efficiency and sustainability indicator ExROExI for proposed SES

Some energy and exergy efficiency data of present electrical devices, calculated according to the second law of thermodynamic, are given in Table $3[8,10]$.

\begin{tabular}{|l|l|l|}
\hline Device & Energy efficiency \% & Exergy efficiency \% \\
\hline Generation & & \\
\hline Coal fired power plant & $40 \div 64$ & $38 \div 62$ \\
\hline Nuclear power plant & 30 & 28 \\
\hline Hydro power plant & 90 & 90 \\
\hline Wind turbine & $0.475 \div 0.576$ & $0.475 \div 0.576$ \\
\hline PV system & $6 \div 25$ & $6 \div 25$ \\
\hline Solar thermal & $10 \div 30$ & $8 \div 25$ \\
\hline Co - trigeneration system & & \\
\hline Cogeneration & 74 & 31 \\
\hline Trigeneration & 94 & 28 \\
\hline Resistance space heater & $\sim 100$ & 6 \\
\hline Hot water heater & 90 & 10 \\
\hline Heat pump -COP 3,8 & 380 & 19 \\
\hline
\end{tabular}

Table 3: Energy and exergy efficiency for selected electrical devices $[8,10]$

Sustainability indicator of the conversion device ExROExI, based on LCExA methodology are for RE defined as quotient of life time of conversion device and expected ExPBT (Eq.5). It can be defined also as quotient of life time exergy produced and cumulative exergy required for construction, maintenance and destruction in the life time, based on meteorological data Exergy for operation, if not from renewable exergy, can be calculated on the same principles. Exergy for equipment destruction or de-commissioning is expected to be from renewable sources at a life time over 30 years. In transition period the exergy for construction will be a mixture of non-sustainable exergy from fossil fuels and sustainable exergy from renewable energy. In first approximation the construction exergy can be calculated as:

$$
\mathrm{Ex}_{\mathrm{c}}=(1-\mathrm{a}) \cdot \mathrm{Ex}_{\mathrm{ct}}
$$

Where

Ex - construction exergy, a - percentage of country exergy produced from renewables, $\mathrm{Ex}_{\mathrm{ct}}-$ total needed construction exergy.

Exergy efficiency of biomass can be calculated as fund, or as exergy of used biomass. In the first case (fund) we have to include the efficiency of solar exergy conversion by plant. If we use the biomass as exergy flow, we have to include exergy for harvesting. Using biomass for the final product e.g. electricity or sin-fuels we have to include all conversion efficiencies.

This methodology should be used when we compare floor area or land use for biomass growth with conversion of solar radiation to final exergy with other conversion technologies. (PV on the land compared with biomass for biofuel or electricity, e.g.). In this case the plant biomass exergy content (high or low heating value of biomass) must be multiplied with this conversion efficiency.

$\eta_{\mathrm{ex}, \mathrm{b}}=\eta_{\mathrm{s}-\mathrm{p}} \cdot \eta_{\mathrm{h}} \cdot \eta_{\mathrm{fc}}$

Where

$\eta_{\text {ex, }}$ - total exergy efficiency for biomass: from solar to final exergy (e.g. electricity)

$\eta_{\mathrm{s}-\mathrm{p}}$ - efficiency solar irradiation to the plant;

$\eta_{\mathrm{h}}$-harvesting efficiency, $\eta_{\mathrm{fc}}$ - conversion efficiency;

$\eta_{\mathrm{fc}}$ - conversion efficiency

\section{Calculations of sustainability indicator ExROExI for SES}

\section{Electricity production}

\section{Photo voltaic system}

PV system consists of PV panel from glass and plastics, under construction in standard design from aluminum profiles, cables and converters. The mean harmonized ExPBT varied from 1.0 to 4.1 years; from lowest to highest, the module types ranked in the following order: cadmium telluride (CdTe), copper indium gallium diselenide (CIGS), amorphous silicon $(\mathrm{a}: \mathrm{Si}), \mathrm{ExPBT}=0.2 \div 1.4$. For poly-crystalline silicon (poly-Si), and mono-crystalline silicon (mono-Si) ExPBT = $1.5 \div 2.7[16,17]$. The mean harmonized ExROExI varied from 3 to 10 with mean 6.6 in [29] and from 8.7 to 34.2 in $[16,17,23]$. The values are always over 1 ; this means that all PV systems are sustainable*.

If we calculate the exergy for construction pro $\mathrm{kW}$ installed, we find that total embedded exergy is between $600 \mathrm{kWh}$ up to 3240 $\mathrm{kWh}$ at $\mathrm{Ex}=1200 \mathrm{kWh} / \mathrm{kW}_{\mathrm{p}, \mathrm{y}}$. The panel cost are 0.6 to $0.4 \$ / \mathrm{W}_{\mathrm{p}}$

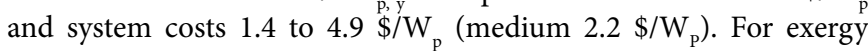
efficiency calculation according to LCExA we need to know the maintenance and destruction exergy. In first approximation (taking into account many different designs of PV system) we will use lifetime of the system $\mathrm{T}_{\mathrm{s}}=30$ years, maintenance exergy $\mathrm{Ex}_{\mathrm{m}}=0.25 \% / \mathrm{y}$ and destruction exergy $\mathrm{Ex}_{\mathrm{d}}=50 \%$ of construction exergy Ex $\mathrm{x}_{c}$. With ExPBT as input, the exergy efficiency can be calculated as:

$$
\varepsilon_{\text {ex }}=\mathrm{T}_{\mathrm{s}} /(\mathrm{ExPBT}+0.025 \mathrm{Ts}+0.5 \mathrm{ExPBT})
$$

Example: For $\mathrm{T}_{\mathrm{s}}=30$ years, ExPBT $=2.7 \mathrm{y}$, exergy efficiency is 6.25 and for ExPBT $=0.2$ y exergy efficiency is $\varepsilon_{\mathrm{ex}}=28.6$.

\section{Hydro}

ExPBT for hydro power plant differs from the size of installation, storage capacity and land use. Hydropower clearly has the highest performance, with exergy ratios exceeding ExROExI $=170$, compared to energy ratios of power plant on fossil fuels between 1.6 and 7. For projects assessed in Quebec, the ExROI $=205$ for hydro with reservoir and 267 for run-of-river hydro (assuming a lifespan of 100 years). Destruction exergy is from renewable sources, so the last term in equation 9 goes to zero. ExROExI for hydropower plant is according to the [21] $\sim 170$ to 267 and according to [28] 21 to 35 , what can be for small hydros. Gupta [29] presents the value of ExROExI from 11.2 to 267 .

*Some authors, based on extended energy analysis, capital investment, including taxes, duties and levies (extended EROEI) find out that EROEI of PV system is only $0,82+1$ $15 \%$. So came to conclusions, that PV systems are unsustainable sink [37] criticizing the IEA expert group, which yield the EROI for PV between 5 to 6 . 


\section{Wind}

Large wind turbines also perform very well. According to the analysis in $[7,24]$ ExROExI is about 19 to 34 for good on-shore sites, depending on wind generator design and meteorological situation. However, this ratio is according to the opinion of some authors overestimated because the assessments do not consider the capacity factor or need for backup capacity to compensate for fluctuations in wind turbine output. Fluctuation of RE conversion technologies will be discussed later. On the other hand in [28] ExROExI for wind is evaluated from 27 to 70 in [29] the ExROExI is given in the range of 18.1 to 24.6. With capacity factor of only $\mathrm{Cp}=0.3$ the ExROExI is still ower 5 in all cases.

\section{Geothermal}

According to the analysis in [19] the exergy efficiency of G-PP with high temperature $\left(165^{\circ} \mathrm{C}\right)$ source without re-injection is $47.6 \%$ and with re-injection is $51.5 \%$. The expected life time is over 50 years. In $[27,28]$ geothermal ExROExI is evaluated from 15 to 40 and for hot dry rock HDR is $6 \div 32$. For ground source heat pumps (GS HP) the ExROExI is $5 \div 7$ [22, 24, 26 and 29].

\section{Biomass for fuel}

Biomass performs well. ExROExI is of 27 when power is produced from forestry wastes [21]. But when trees are planted for the purpose of producing electricity, the ExROExI is much lower (about 3 to $5)$, because biomass plantations require high energy inputs. For all biomass options, the distance between the source of biomass and the power plant must be short; otherwise the energy payback ratio drops to very low values.

Based on real data in case of bio-ethanol production in Brasilia the total efficiency from solar irradiation to ethanol, presently achievable with the BAT, is only $0.032 \%$ [25]. In [29] the data for ExROExI of ethanol from corn is 0.8 to 2.1 (based on corn exergy).

\section{Hydrogen, oxygen}

Hydrogen in SES is an intermediate product for renewable electricity storage and as input mater for synthesis of methane and methanol. Hydrogen can be produced from renewable electricity when supply overrides the electricity consumption. For hydrogen we need also storage. The hydrogen can be economically stored if

$$
\frac{\text { ExSOExI }}{\operatorname{ExROExI}}>1-\Phi
$$

Where

ExSOExI (Exergy storage return of exergy invested) is analogous to ExROExI, it is the ratio of exergy (electricity) stored over the lifetime in a storage device to the amount of embodied electrical energy required to build the device. ExSOExI is specially defined for the purpose of comparison of different storage. $\Phi$ is surplus of exergy - electricity - needed to be stored.

For hydrogen production using the water electrolysis we need $54-$ $67 \mathrm{kWh} / \mathrm{kg}$ of H2. Efficiency is 0.56 to 0.73 , depending on conversion technology [26, 27]. ExROExI for hydrogen from fossil fuels is less than 1.5 [28]. Exergy for water splitting from renewable energy is free flow and is not taken into account. ExROExI for hydrogen conversion with RE is not yet published.
Other possibilities to store the renewable electricity are the batteries. ExSOExI for $\mathrm{Pb}$ batteries is 5, for $\mathrm{Li}$-ion batteries 32, for pumping hydro storage (PHS) ExSOExI $=704$ and for compressed air energy storage ExSOExI = $792[35]$

Oxygen, as by-product of electrolysis can be used for production of s-methanol from biomass.

\section{Methane}

For methane production we need one atom of carbon and four atoms of hydrogen. The source for carbon in SES is biomass (waste). The methane production from biomass is a known process which can be realized with different technologies [30]. The present technology is known as "power to gas" using the renewable electricity for production of hydrogen and hydrogen to methane with $\mathrm{CO}$ or $\mathrm{CO} 2$. As proposed in SES only the waste biomass can be a source of carbon for synthetic methane (s-methane). Total efficiency of exergy conversion from electricity to electricity is $30-38 \%$ and for CHP from 43 to $54 \%$, depend on used technologies [30], which is comparable to the present fossil fuel power plant. ExPBT and ExROExI are not published, but expected ExROExI to be over $1.5 \div 5$.

\section{Methanol}

For synthesis of methanol the biomass is gasified and the resulting synthesis gas, a mixture of $\mathrm{CO}, \mathrm{H} 2$ and $\mathrm{CO} 2$ is adapted to the quality requirements of $\mathrm{MeOH}$ synthesis. During the synthesis the following reactions occur:

$$
\begin{aligned}
& \mathrm{CO}+2 \mathrm{H}_{2} \Leftrightarrow \mathrm{CH} 3 \mathrm{OH} \\
& \mathrm{CO}_{2}+3 \mathrm{H}_{2} \Leftrightarrow \mathrm{CH} 3 \mathrm{OH}+\mathrm{H} 20 \\
& \mathrm{CO}_{2}+\mathrm{H}_{2} \Leftrightarrow \mathrm{CO}+\mathrm{H}_{2} \mathrm{O}
\end{aligned}
$$

For each carbon atom in biomass we need four atoms of hydrogen and one atom of oxygen. Only a small part of hydrogen and oxygen is present in the biomass. The rest of needed hydrogen should be supplied from other sources (from water splitting with renewable electricity). The formation of methanol is exothermic and is favoured by high pressures and low temperatures. For efficiency improvement, process simplification, investment cost reduction and exergy consumption reduction different alternatives are under development.

This new development could also be used also for methanol production from biomass. Direct oxidation of methane is the next possibility: $2 \mathrm{CH}_{4}+\mathrm{O}_{2} \Leftrightarrow 2 \mathrm{CH}_{3} \mathrm{OH}$ using oxygen from the electrolysis $[31,35]$. ExROExI for methanol production using renewable exergy is not published, but expected value is $2 \div 5$.

Using the present devices in SES the sustainability has been guaranteed even though the present technology is not optimized. Exergy costs are higher than those from fossil fuels, whose production and use are always unsustainable and do not include the externalities.

\section{Balancing of The Energy/Exergy System}

Because of the high intermittences of RE adaptation to the exergy load (special electrical load) the main responsibility of new exergy system designer is to fulfil the three important requirements of exergy supply:

\section{Decarbonisation (from fossil fuels carbon) \\ 2. Security of supply \\ 3. Competition}




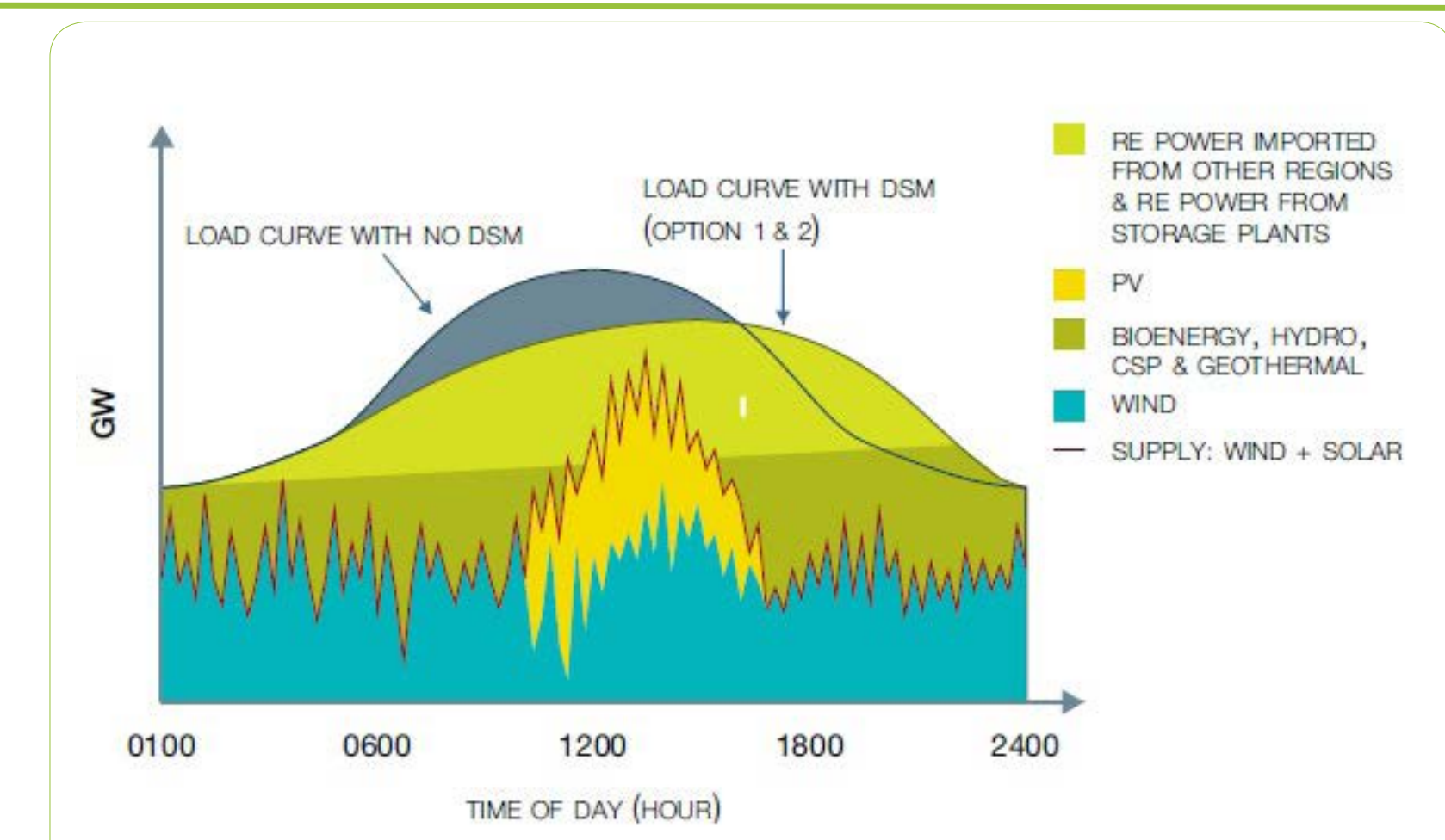

Figure 6: An optimized system with ower $90 \%$ renewable energy supply [34].

Using a combination of different renewable sources (solar irradiation, wind, hydro, biomass, chemical storage, s-gas, s-liquid exergy carrier with demand side management - DMS, the load can be satisfied in maximal manner even at $90 \%$ share of RE in SES. The regional cooperation should be included as is proposed in Figure 6 from Greenpaece International 2017 [34]. Using the liquidfuels $\mathrm{s}$-methanol the balancing of the system is becoming easier, especially in winter times with low sun irradiation. Storage of the methanol is inexpensive and for long term with no loss of exergy of stored liquid. This is not the case in batteries and gas storages.

\section{Conclusions}

In articles we show, that resources cannot be evaluated only according to mass and energy balance, because they do not disappear. Energy cannot be consumed; it can be only transformed in different forms. Using the exergy as the measure of resource depletion we can evaluate the quality of our processes taking into account the conservation of mass and energy. Exergy is also closely connected with sustainability. Sustainable development means less exergy destruction or depletion.

Circular economy promoted in the last years is a policy to minimize the resources destruction, which means minimizing the thermodynamics irreversibiliesties with higher exergy efficiency. To push the circular economy on the top of society development we need a serious exergy analysis during the life cycle (LCExA) of present technologies and economic patterns. The exergy destruction during a process is proportional to the entropy created due to irreversibilities associated with the process therefore exergy analysis can clearly indicate the locations of energy degradation in a process that may lead to improved operation or technology.

Exergy approach to evaluate the sustainability of present energy system using the $\mathrm{E}_{\mathrm{x}} \mathrm{ROExI}$ as sustainability indicator gives us the possibility to make a distinction between fossil fuels conversion technologies and technologies for conversion of renewable sources of energy. To fulfill the requirement of sustainability indicator ExROExI should be 1 or more.

The most important fact is that $\mathrm{E}_{\mathrm{x}} \mathrm{ROExI}$ of RE is time independent, even more, with better technologies it will raise with time. On the other hand $\mathrm{E}_{\mathrm{x}}$ ROExI of fossil fuels are descending with time, because of internalization of external costs and growing costs of fossil fuels mining from the Earth. In our case LCExA and E ROExI has been used to analyze sustainable energy system, based on organic carbon circulation in future circular economy.

Natural resources are classified as natural flows and stocks. Stocks are then divided into deposits and funds. Deposits are non-renewable while funds are renewable. Renewable exergy input in our analysis has been disregarded since it represents a natural flow. If not used, natural exergy flows will be wasted and lost as anergy - heat of environment.

Based on this background we proposed a sustainable exergy system without any GHG emissions. The sustainable exergy system (SES) as proposed in [16] consists of three main renewable exergy carriers, needed in industry, transport, commercial and homes: renewable electricity, gas (synthetic methane $\mathrm{CH}_{4}$; s-methane), liquid (synthetic methanol $\mathrm{CH}_{3} \mathrm{OH}$; s-methanol) and as fourth exergy carrier solid fuels from biomass, important for developing countries in transition period. Renewable electricity is the main driver in the system. It is proposed using the surplus of electricity ower the demand for transformation of two natural flows into two new exergy carriers: water and biomass. Those are used also as chemical storage of solar electricity, solving the problem of intermittency of RE.

To fulfill the daily exergy needs of different consumers, the new exergy system has to fulfill the following six main requirements: 1) 
source of exergy must be inexhaustible, available everywhere on the planet; 2) new exergy carriers with zero emission of GHG; 3) must be available at any place and any time; 4) must be compatible with existing infrastructure; 5) in transition period enables coexistence of two systems; 6) should be competitive.

We show that proposed SES fulfills at large all six requirements. All proposed energy carriers in the new SES have the ExROExI more than 1. This means that the proposed sustainable energy system is longterm sustainable and from the social point of view acceptable for all countries on the planet Earth. Those not having enough biomass for carbon recycling have more direct solar exergy and can cover their needs for organic carbon by international trade of solar electricity to biomass.

We have to stress, that the proposed SES can exist with the present one in transition time to $100 \%$ of RE supply and is able to use most of the present infrastructure for distribution and conversion of proposed exergy carriers.

\section{Competing Interests}

The author declares that they have no competing interests.

\section{References}

1. ECO Design Directive, 2009/125/EC; Renewable Energy Directive 2009/28/EC; Energy Efficiency Directive 2012/27/EU; EPDB 2010/31/EU; Energy Union $/{ }^{*} \mathrm{COM} / 2015 / 080$ final ${ }^{*} /$, Closing the loop - An EU action plan for the circular economy, /COM (2015) 614 final/,

2. http://eur-lex.europa.eu/resource.html?uri=cellar:1bd46c90-bdd4-11e4bbe1-01aa75ed71a1.0001.03/DOC_1\&format=pdf.

3. http://eur-lex.europa.eu/resource.html?uri=cellar:8a8ef5e8-99a0-11e5b3b7-01aa75ed71a1.0012.02/DOC_1\&format=pdf.

4. Kabelac S (2005) Exergy of solar radiation. Int J Energy Technology and Policy 3: 115-122.

5. Zamfirescu C, Dincer I (2009) How much exergy one can obtain from incident solar radiation. J of Applied Physics 105: 044911

6. Neri M, Luscietti D, Pilotelli M (2013) Computing the exergy of solar radiation from real radiation data. J Energy Resour Technol 139: 061201.

7. Davidsson S (2011) Life Cycle Exergy Analysis of Wind Energy system.

8. Rosen AM, Bulucea AC (2009) Using Exergy to Understand and Improve the Efficiency of Electrical Power System. J Entropy 11: 820-835.

9. Rant Z (1955) Strojniški vestnik. Ljubljana 1: 1-3

10. The exergy calculator

11. Jacobson MZ, Delucchi MA (2011) Providing all global energy with wind, water, and solar power, Part I, Part II: Technologies, energy resources, quantities and areas of infrastructure, and materials. Energy Policy 39: 1154-1169.

12. https://en.wikipedia.org/wiki/Biomass

13. https://en.wikipedia.org/wiki/Geothermal_energy

14. US DOE: U.S. Energy Information Administration / AEO2017 Levelized Costs /

15. https://en.wikipedia.org/wiki/Wind_wave

16. Novak P (1990) The way to the energy sustainable world. Energy and Buildings 14: 249-256.

17. Goe M, Gaustad G (2014) Strengthening the case for recycling photovoltaic: An energy payback analysis. Applied Energy 120: 41-48.

18. Yue D, You F, Darling SB (2014) Domestic and overseas manufacturing scenarios of silicon-based photovoltaic: Life cycle energy and environmental comparative analysis. Solar Energy 105: 669-678.
19. Krebs FC (2009) Fabrication and processing of polymer solar cells: a review of printing and coating techniques. Solar Energy Materials and Solar Cells 93: 394-412.

20. Bhandari KP, Collier JM, Ellingson RJ, Apul DS (2015) Energy payback time (EPBT) and energy return on energy invested (EROI) of solar photovoltaic systems: A systematic review and meta-analysis. Renewable and Sustainable Energy Reviews 47:133-141.

21. Bhat VIK, Prakash R (2008) Life Cycle Analysis of Run-of River Small Hydro Power Plants in India. The Open Renewable Energy Journal 1: 11-16.

22. Self SJ, Reddy BV, Rosen MA (2015) Energy and exergy analyses of geothermal plants with and without re-injection. Research Journal of Environmental Science 9: 74-87.

23. Bhandarib KP, Colliera JM, Ellingsonb RJ, Apul DS (2015) Energy payback time (EPBT) and energy return on energy invested (EROI) of solar photovoltaic systems: A systematic review and meta-analysis. Renewable and Sustainable Energy Reviews 47: 133-141.

24. Comparing Energy Options

25. Novak P (2012) Full cycle from solar irradiation to the ethanol, sugar cane to ethanol, Brasilia, EEA Seminaron Biomass, Copenhagen 2010; EEA Seminar: Transport, Mobility and Environment, Ljubljana.

26. Kewen Li (2013) Comparison of geothermal with solar and wind power generation systems, proceedings, Thirty-Eighth Workshop on Geothermal Reservoir Engineering Stanford University, Stanford, California,

27. Pandeyr S, Saini H (2014) A techno-energetic review on hydrogen production using wind energy. International Journal of Innovation and Scientific Research 2: 312- 321

28. Kimball J (2011) Energy Return on Investment (EROI) for U.S. Oil and Gas Discovery and Production.

29. Gupta AK, Hall CAS (2011) A Review of the Past and Current State of ERO Data. Sustainability 3: 1796-1809.

30. https://de.wikipedia.org/wiki/Power-to-Gas

31. http://www.biofuelstp.eu/factsheets/methanol-fact-sheet.html

32. Wall G, Gong M (2001) On exergy and sustainable development-Part 1: Conditions and concepts. Exergy Int J 1: 128-145.

33. Sciuba E, Wall G (2007) A brief Commented History of Exergy From the Beginnings to 2004. Int $\mathrm{J}$ of Thermodynamics 10:1-26.

34. http://www.greenpeace.org/international/Global/international/publications/ climate/2015/Energy-Revolution-2015-Full.pdf

35. Zhen X, Wang Y (2015) An overview of methanol as an internal combustion engine fuel, Renewable and Sustainable Energy Reviews 52: 477-493.

36. Barnhart CJ, Dale M, Brandt AR, Bensona SM (2013) The energetic implications of curtailing versus storing solar- and wind-generated electricity. Energy Environ Sci 6: 2804-2810.

37. Ferroni F, Hopkirk RJ (2017) Energy Return on Energy Invested (ERoEI) for photovoltaic solar system in regions of moderate insolation. Energy Policy 94: $336-344$ 